Proc. Estonian Acad. Sci. Geol., 1996, 45, 4, 189-202

\title{
LOGANELLIA (THELODONTI, AGNATHA) FROM THE JAAGARAHU STAGE, WENLOCK, ESTONIA
}

\section{Tiiu MÄRSS}

Geoloogia Instituut (Institute of Geology), Estonia pst. 7, EE-0001 Tallinn, Eesti (Estonia)

Presented by D. Kaljo

Received 15 May 1996, accepted 3 June 1996

\begin{abstract}
Based on the differences in the morphology of the scales, Loganellia einari sp. nov. is separated from Loganellia grossi Fredholm. Trunk scales of $L$. einari sp. nov. are elongated with distinct longitudinal ridges on the crown. A pair of ridges is located medially and up to six ridges on both sides of the crown. The separation of the species is supported by their different stratigraphical positions: $L$. einari sp. nov. occurs above $L$. grossi in sections and forms the $L$. einari Zone in the Tagavere Beds of the Jaagarahu Stage, Wenlock. $L$. grossi Fredholm is redescribed.
\end{abstract}

Key words: Agnatha, Thelodonti, Lower Silurian, Wenlock, Estonia.

\section{INTRODUCTION}

The study of the thelodont genus Loganellia from the Jaagarahu Stage of Estonia started in 1986. Its scattered scales, recorded from the Maasi and Tagavere beds of the stage, were described under the name of Logania taiti (Stetson) (see Märss, 1986, pp. 26-29, text-fig. 11, Pls. X, XI). The collection contained the scales of different morphology and sculpture.

Later Fredholm (1990), studying Lower Silurian vertebrates of Gotland, found scales similar to the East Baltic ones in the upper Slite Beds (units $f$, $g$, and the top). She showed that this species could not be identified as L. taiti and distinguished Loganellia grossi $\mathrm{n}$. sp. (the genus name Logania was replaced by Loganellia by Turner in 1991).

Recently the type material of Scottish articulated thelodonts, including Shielia (= Loganellia) taiti (Stetson), was redescribed (Märss \& Ritchie, submitted). There appeared a necessity to revise Loganellia grossi, as the 
variability of its scales had been considered more widely than seemed to be justified after our study of articulated Loganellia species. In the present work Loganellia scales from the Slite Beds, Wenlock of Gotland, are considered as well.

\section{STRATIGRAPHICAL DISTRIBUTION}

Two Loganellia species described below were studied in ten borehole cores of Saaremaa Island and from one core in the western part of Estonian mainland, near the village of Paatsalu (Fig. 1).

Different argillaceous dolomites of the Jaagarahu Stage were dissolved in acetic acid. In the residue three main types of the scales could be firmly identified: (1) rounded or oak-leaf-shaped oral and cephalo-pectoral scales having a similar outline in most loganiids; (2) scales with a smooth surface or with a shallow short median groove on the rhomboidal crown plate, and down-stepped lateral rims, now known as L. grossi; (3) scales with distinct longitudinal ridges on the crown comprising a pair of medial and up to six pairs of lateral ones. Owing to these differences in the scale morphology, it is reasonable to consider only the second type as $L$. grossi and to establish a new species, L. einari, on the basis of the third type of the scales.

In the sections studied $L$. einari sp. nov. is distributed above $L$. grossi (Fig. 1). The best example is the Sakla core section where the samples from the interval 68.4-77.0 m, belonging to the Maasi Beds (Jaagarahu Stage), yield $L$. grossi while $L$. einari sp. nov. appears at a depth of $62.7 \mathrm{~m}$ and ranges up to $58.2 \mathrm{~m}$, i.e. it occurs in the Tagavere Beds of the same stage. In the Tamba, Kaarmise, and Kuressaare core sections only L. grossi is distributed in the Maasi Beds, in the Paadla and Eikla cores L. einari sp. nov. occurs alone in the Tagavere Beds.

The material from the Vesiku and Valjala core sections is important for establishing changes in the scale morphology. The samples from the lower parts of these sections (depth $46.2 \mathrm{~m}$ in the Vesiku core and 45.0-57.4 m in the Valjala core) contain scales of $L$. grossi with a smooth crown plate. Higher (samples from 23.7-27.9 $\mathrm{m}$ in the Vesiku core and $39.8 \mathrm{~m}$ in the Valjala core) the scales have a median longitudinal groove. Ridged scales of $L$. einari sp. nov. are not found in these cores.

In some sections the samples from the lower part of the Jaagarahu Stage contain scales which can be identified as $L$. grossi with some doubt, e.g. in the Ohesaare core, depth $174.1 \mathrm{~m}$, in the Riksu core, depth $100.6 \mathrm{~m}$, and in the Kipi core, depth $72.0 \mathrm{~m}$, there were found rare small scales with a gentle groove on the crown resembling more $L$. scotica than $L$. grossi.

It should be pointed out that the depth of the interval $28.6-38.9 \mathrm{~m}$ in the Vesiku core (see Märss, 1986, Fig. 27) was not established correctly by 


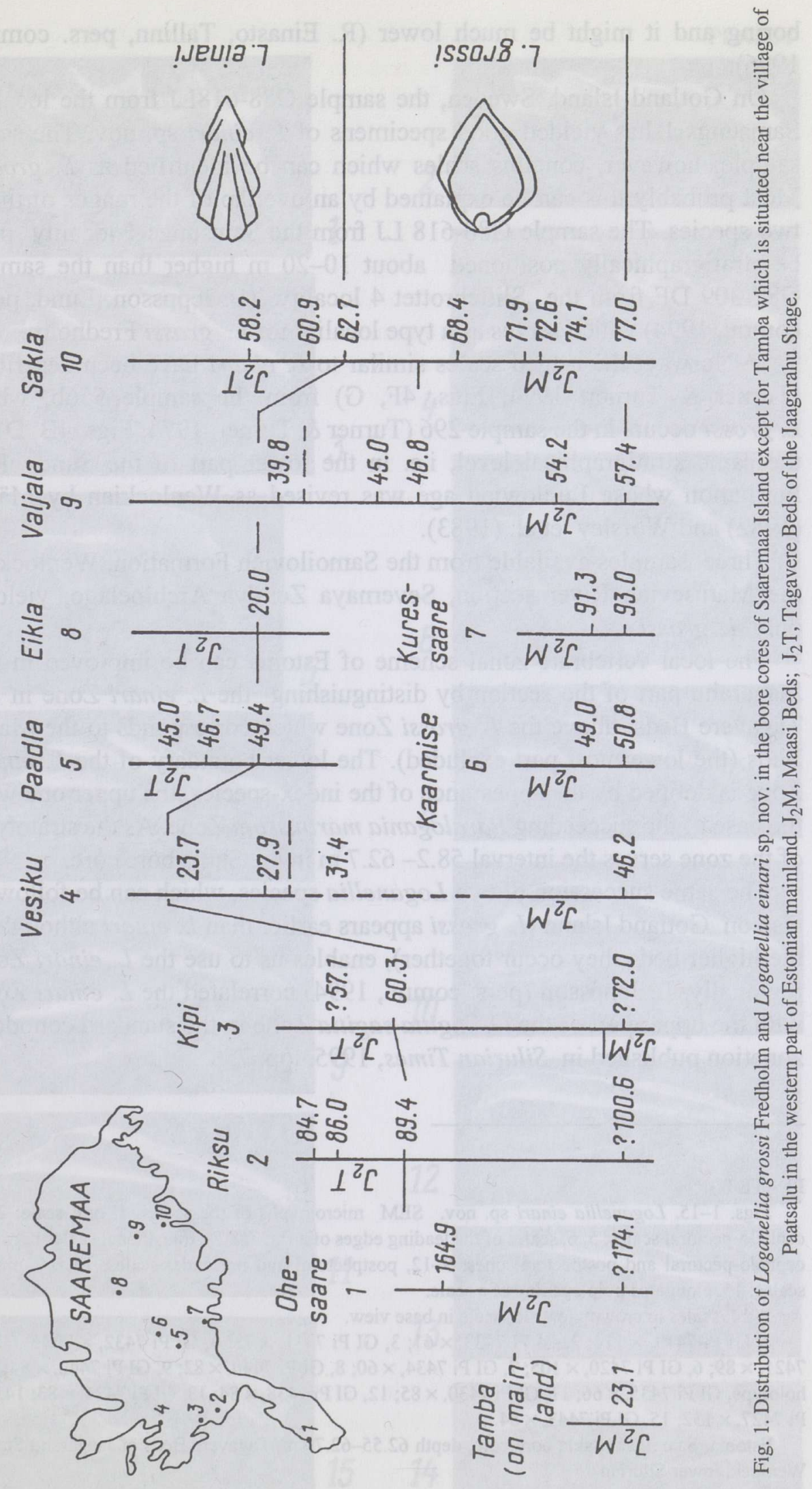


boring and it might be much lower (R. Einasto, Tallinn, pers. comm., 1996).

On Gotland Island, Sweden, the sample G88-618LJ from the locality Samsungs 1 has yielded good specimens of $L$. einari sp. nov. The same sample, however, contains scales which can be identified as $L$. grossi. Most probably this can be explained by an overlap of the ranges of these two species. The sample G88-618 LJ from the Samsungs 1 locality may be stratigraphically positioned about $10-20 \mathrm{~m}$ higher than the sample G87-309 DF from the Slittebrottet 4 locality (L. Jeppsson, Lund, pers. comm., 1994) which serves as a type locality for $L$. grossi Fredholm.

In Norway, the ridged scales similar to $L$. einari have been described (Turner \& Turner, 1974, Figs. 4F, G) from the sample 556b, while L. grossi occurs in the sample 296 (Turner \& Turner, 1974, Figs. 4B, D) of the same stratigraphical level, i.e. in the lower part of the Sundvollen Formation whose Ludlowian age was revised as Wenlockian by Märss (1982) and Worsley et al. (1983).

Three samples available from the Samoilovich Formation, Wenlock of the Matusevich River section, Severnaya Zemlya Archipelago, yielded only $L$. grossi.

The local vertebrate zonal scheme of Estonia can be improved in the Jaagarahu part of the section by distinguishing the L. einari Zone in the Tagavere Beds above the L. grossi Zone which corresponds to the Maasi Beds (the lowermost part excluded). The lower boundary of the $L$. einari Zone is defined by the appearance of the index-species, the upper one with the base of the succeeding Paralogania martinssoni Zone. As the stratotype of the zone serves the interval 58.2-62.7 $\mathrm{m}$ in the Sakla bore core.

The same succession of two Loganellia species, which can be followed also on Gotland Island (L. grossi appears earlier than L. einari although in the higher beds they occur together), enables us to use the L. einari Zone regionally. L. Jeppsson (pers. comm., 1994) correlated the L. einari Zone with the upper part of the $O$. sagitta sagitta Zone in the standard conodont zonation published in Silurian Times, 1995, pp. 7, 8.

PLATE I

Figs. 1-15. Loganellia einari sp. nov. SEM micrographs of the scales. 1, oral scale; $2-4$, cephalo-pectoral scales; 5,6 , scales of the leading edges of a fin; $7,8(?)$, transitional scales between cephalo-pectoral and postpectoral ones; 9-12, postpectoral and precaudal scales; 13, 14, pinnal scales; 15 , elongated pulp opening of a scale.

$1-14$, scales in crown view; 15 , scale in base view.

1, GI Pi 7419, × 114; 2, GI Pi 7433, ×61; 3, GI Pi 7431, ×73; 4, GI Pi 7432, ×92; , GI Pi $7421, \times 89 ; 6$, GI Pi 7420, $\times 105 ; 7$, GI Pi 7434, $\times 60 ; 8$, GI Pi 7440, $\times 82 ; 9$, GI Pi 7442, $\times 84 ; 10$, holotype, GI Pi 7435, $\times 66 ; 11$, GI Pi 7430, × 85; 12, GI Pi 7438, ×84; 13, GI Pi 7424, × 83; 14, GI Pi $7427, \times 132 ; 15$, GI Pi $7443, \times 84$.

Estonia, Saaremaa, Sakla bore core, depth $62.55-62.70$ m, Tagavere Beds of Jaagarahu Stage, Wenlock, lower Silurian. 

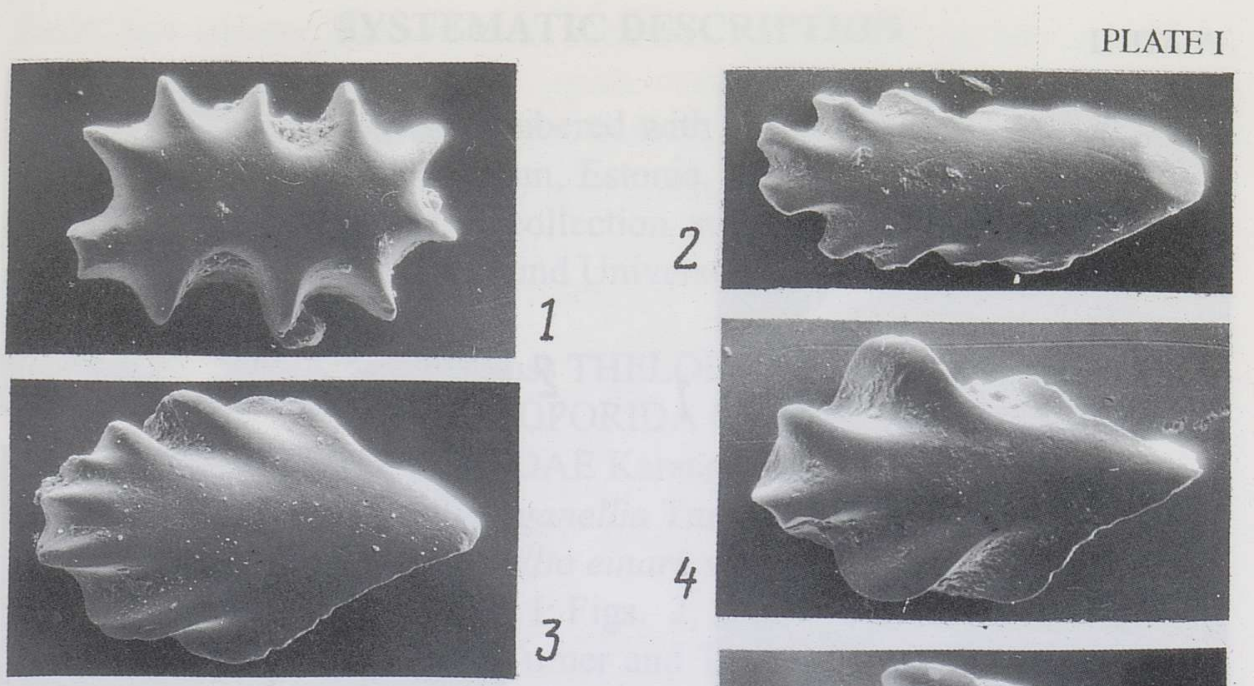

1

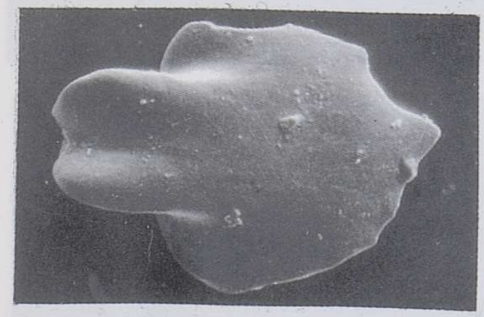

5
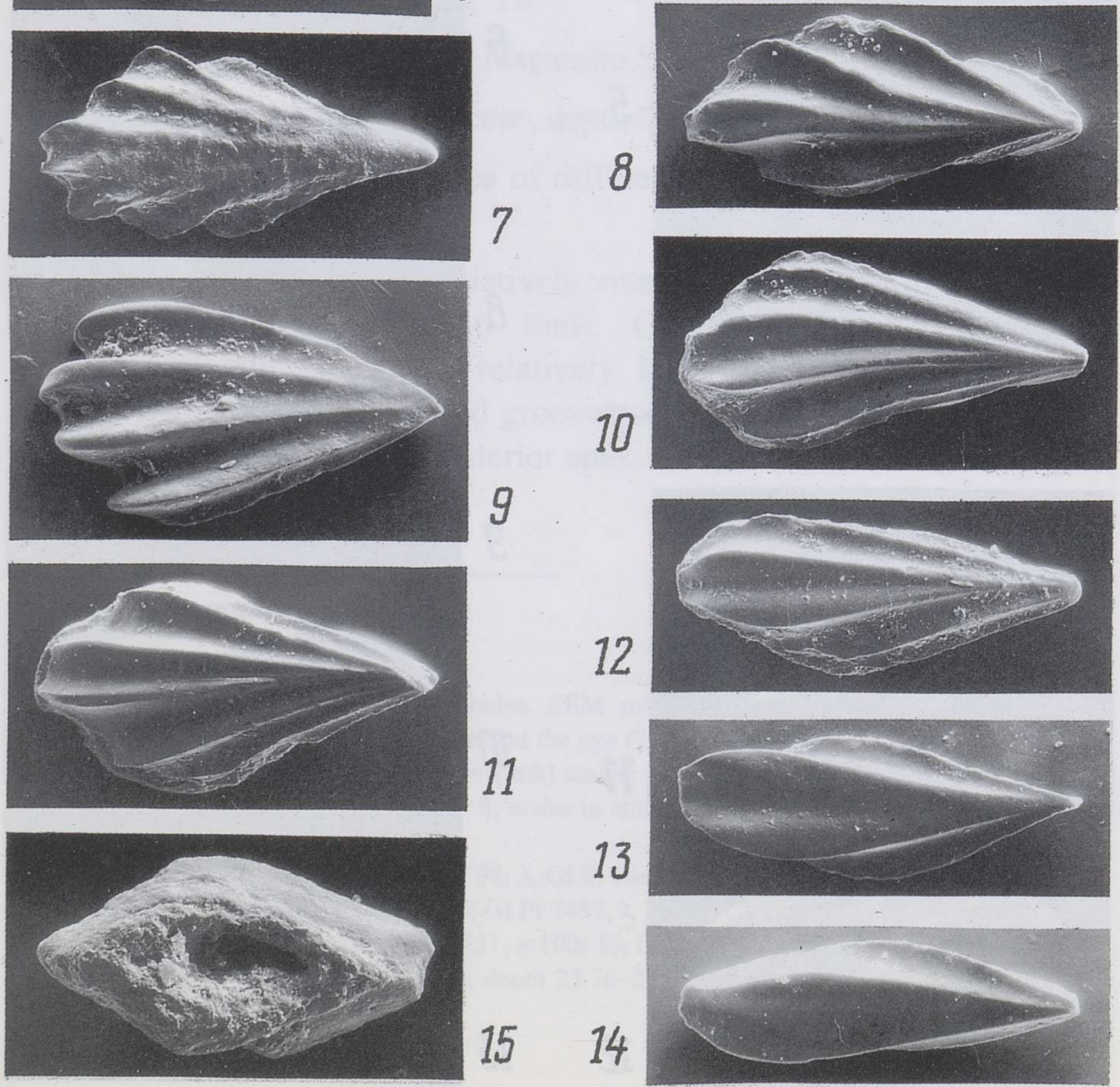

3
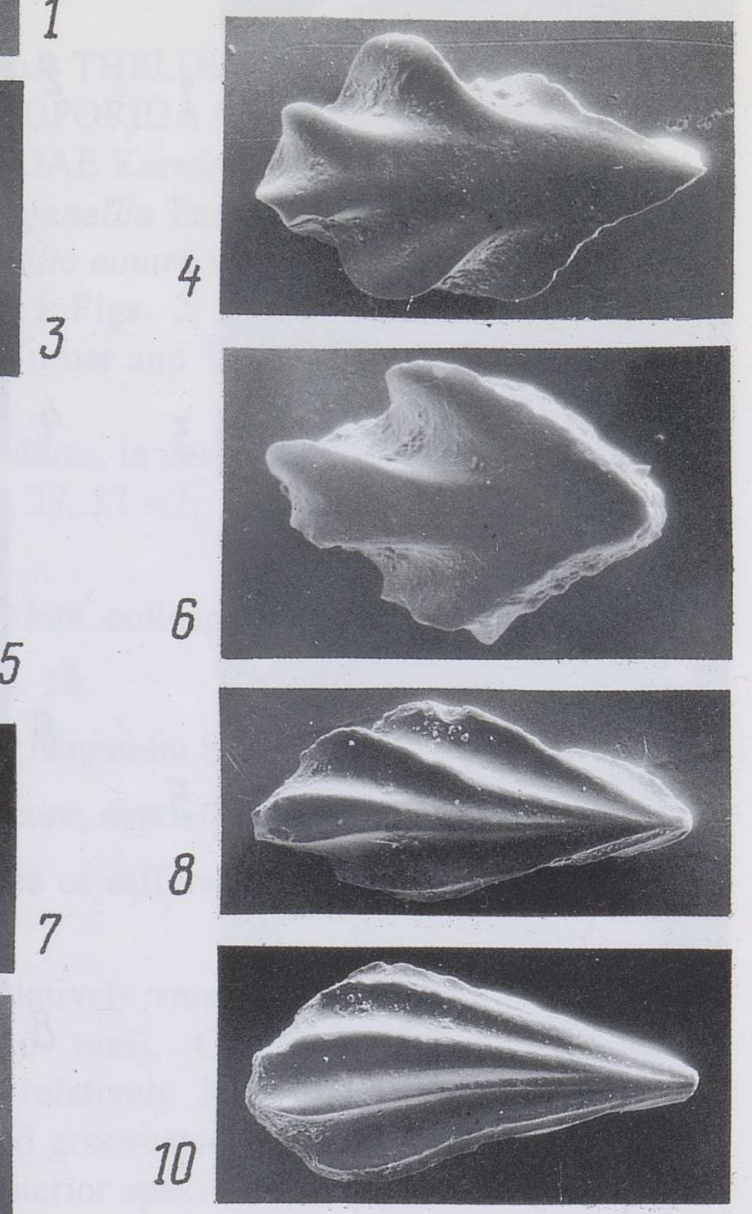

9

15

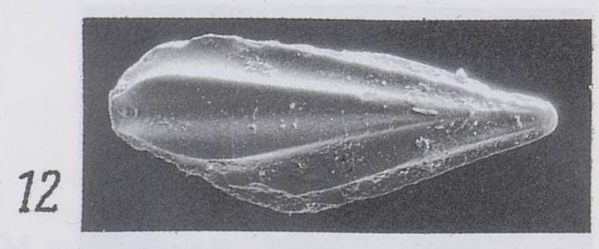

11

13
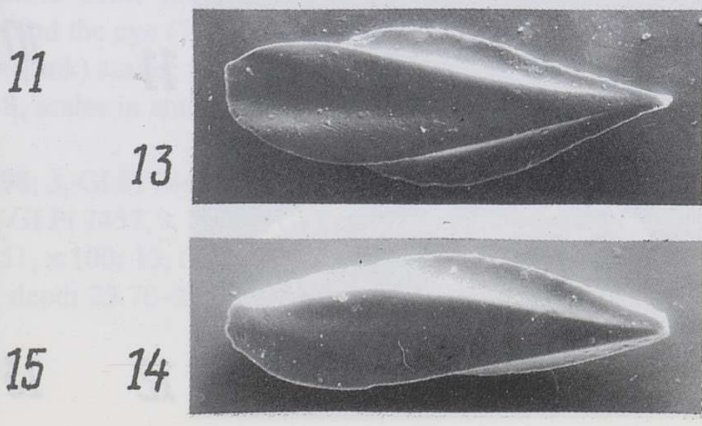
PLATE II
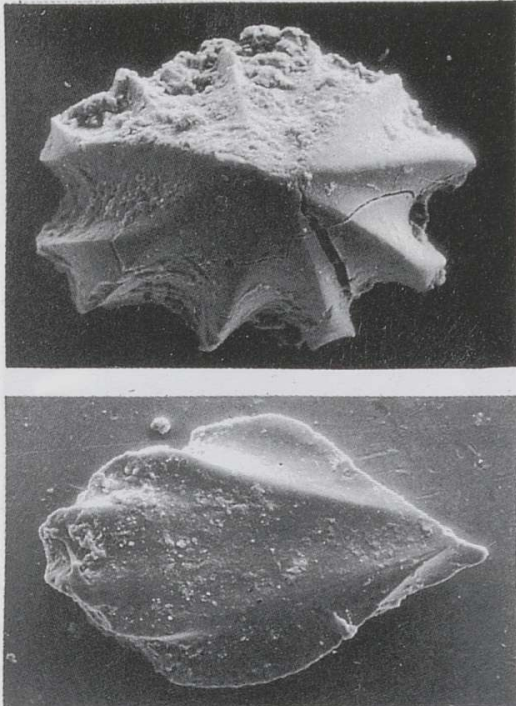

3

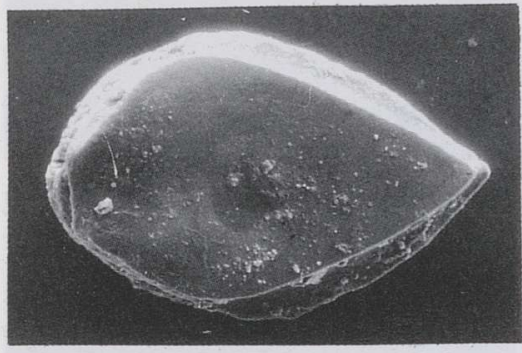

5
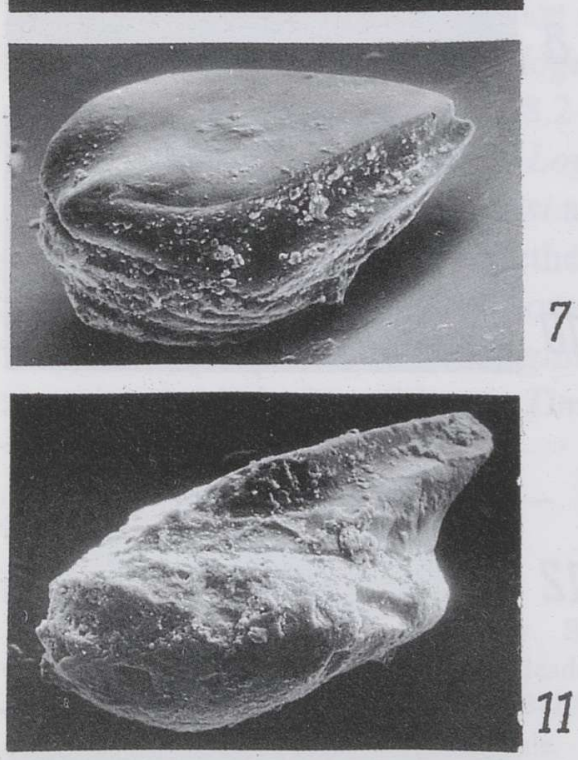

11

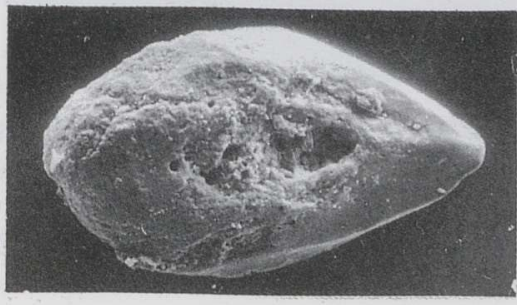

1

7
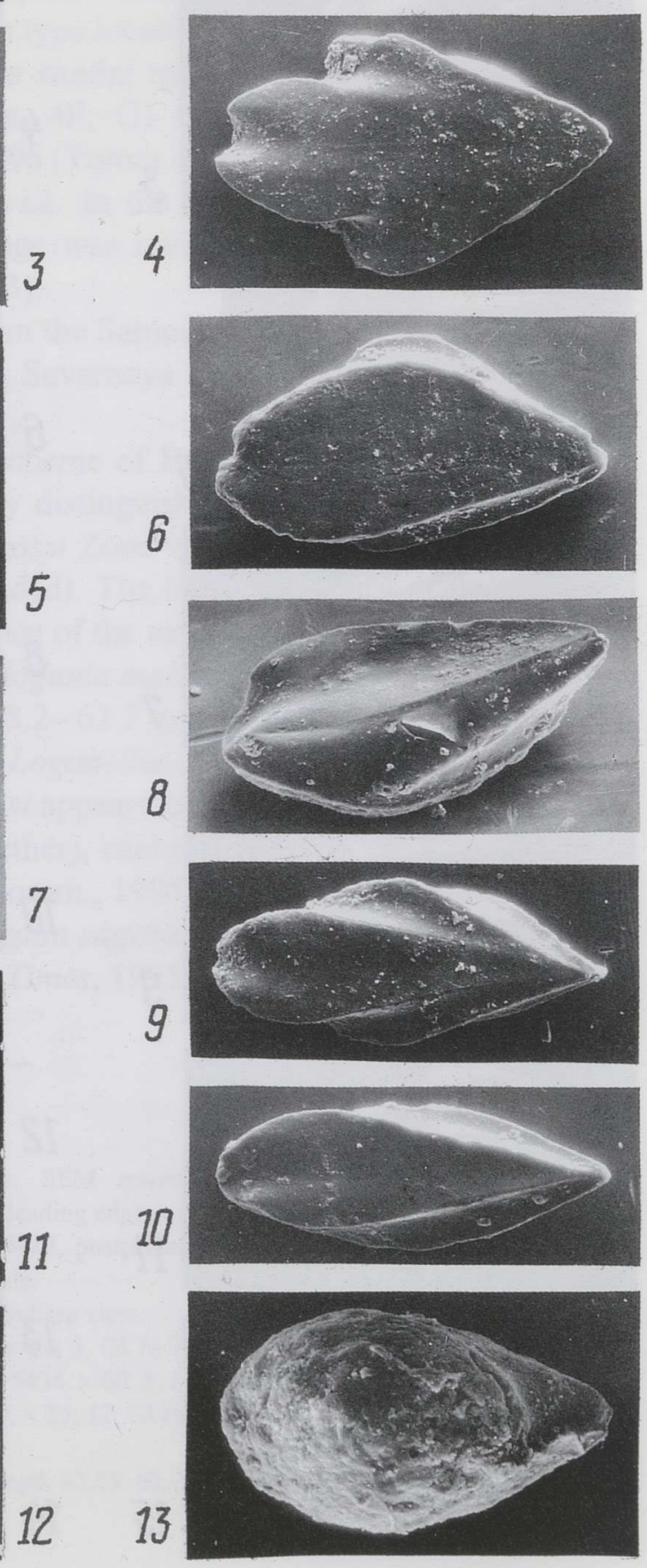


\title{
SYSTEMATIC DESCRIPTION
}

Repository. Specimens numbered with the letters GI Pi are housed in the Institute of Geology, Tallinn, Estonia, and specimens marked LO + the number are in the Type collection at the Department of Historical Geology and Palaeontology, Lund University, Sweden.

\author{
Subclass THELODONTI \\ Order KATOPORIDA Gross, 1967 \\ Family LOGANIIDAE Karatajute-Talimaa, 1978 \\ Genus Loganellia Turner, 1991 \\ Loganellia einari sp. nov. \\ Pl. I; Figs. 2, $3 \mathrm{~A}$
}

1974 Logania taiti (Stetson); Turner and Turner, in partim, pp. 187-188, Fig. $4 \mathrm{~F}, \mathrm{G}$.

1986 Logania taiti (Stetson); Märss, in partim, pp. 26-29, Fig. 11: 1, 3, 4, 5, 7, 9, 11, 12, 16, 20, 22, 27, 37-47; Pl. X, Figs. 3-8, 13, 15, 16, 18; Pl. XI, Figs. 6-8.

Derivation of the name. After late colleague Einar Klaamann.

Holotype. GI Pi 7435, P1. I, fig. 10.

Type horizon. Tagavere Beds, Jaagarahu Stage, Wenlock, lower Silurian.

Type locality. Sakla borehole core, depth 62.55-62.70 m.

Material. More than 200 scales of different preservation; very often the scales have lost their bases.

Diagnosis. Loganellia with relatively small scales (length of the crown $0.2-1.1 \mathrm{~mm}$, width $0.15-0.6 \mathrm{~mm}$ ). Crowns of the trunk scales (postpectoral and precaudal) relatively long, pointed posteriorly, and covered with distinct ridges and grooves converging on the posterior part of the crown in front of the posterior apex. There occur five (in cephalo-

\section{PLATE II}

Figs. 1-13. Loganellia grossi Fredholm. SEM micrographs of the scales. 1, oral scale; 2 , cephalo-pectoral scale; 3 , scale from behind the eye (?); 4 , scale from the leading edge of a fin; $5-9,11-13$, postpectoral and precaudal (= trunk) scales; 10 , scale from the fin.

$1-6,9,10$, scales in crown view; 7,8 , scales in antero-lateral view; 11 , scale in lateral view; 12,13 , scales in base view.

1, GI Pi $7445, \times 129 ; 2$, GI Pi $7466, \times 98 ; 3$, GI Pi $7448, \times 127 ; 4$, GI Pi $7449, \times 76 ; 5,7$, GI Pi 7456, appr. × 136; 6, GI Pi 7455, × 115; 8, GI Pi 7457, × 115; 9, GI Pi 7458, ×115; 10, GI Pi 7461, $\times 135 ; 11$, GI Pi 7454, × 110; 12, GI Pi 7451, × 100; 13, GI Pi 7464, × 150 .

Estonia, Saaremaa, Vesiku bore core, depth $23.70-23.85$ m, Maasi Beds of Jaagarahu Stage, Wenlock, lower Silurian. 
pectoral scales up to six) ridges on both sides from the medial one. Neck reminds of a shallow groove. Base deep, pulp opening located centrally or posteriorly. Pulp canal developed. Dentine canals narrow.

Description. Morphology. As all thelodonts, L. einari $\mathrm{sp}$. nov. has nearly rounded to oval, often irregular outline of the scales on the anterior part of the body (Pl. I, fig. 1; Fig. 2, 1-7), referred to as oral by Märss (1986). The scale crowns are usually flat or slightly convex, sometimes conical, with strongly crenulated edges. The notches are directed towards the centre of the crown. The base in the mature scales is relatively deep and nearly of the same width as the crown. The neck is weakly developed having the shape of a shallow groove. The pulp depression or opening is situated in the centre of the crown.

The crowns of the cephalo-pectoral scales (Pl. I, figs. 2-4; Fig. 2, 8-14) are slightly convex, elongated, narrowing posteriorly, in configuration often resembling an oak leaf. The radial crenulation turns to short, longitudinally directed ridges and grooves, distributed antero-laterally of the crowns. The median triangular part of the crown is not distinctly separated from the lateral ones. Usually the crowns are wider and longer than the bases. The latter can be relatively deep.

There occur scales with crowns distinctly divided into three parts: the median (sometimes bifurcated) and the lateral ones (Pl. I, figs. 5, 6; Fig. 2, 27). The morphology of these scales was one of the reasons for uniting the ridged and smooth scales into one species (Märss, 1986, pp. 26-29). The studies on the articulated Loganellia specimens from Scotland have showed (Turner, 1991; Märss \& Ritchie, submitted) that the scales of such morphology are situated on the leading edges of the fins.

The scales in Pl. I, figs. 7, 8(?); Fig. 2, 15, 16, 19 represent transitional scales from the cephalo-pectoral to the postpectoral area, having large elongated crowns with deep furrows and up to six ridges laterally from the medial one. The ridges do not reach the posterior end of the crown.

Fig. 2. Loganellia einari sp. nov. The main morphological scale varieties. 1-7, oral scales; 8-14, cephalo-pectoral scales; $15,16,19$, transitional scales between cephalo-pectoral and postpectoral ones; $17,18,20-26,28-31$, postpectoral and precaudal scales; 27 , scale of the leading edge of a fin; 32-34, pinnal scales. All scales $\times 45$.

1, GI Pi 5741; 2, GI Pi 5748; 3, GI Pi 5753; 4, GI Pi 6116; 5, GI Pi 5751; 6, GI Pi 6749; 7, GI Pi $5750 ; 8$, GI Pi $7283 ; 9$, GI Pi 5752; 10 , GI Pi 5757; 11 , GI Pi 5742; 12 , GI Pi $6117 ; 13$, GI Pi $6118 ; 14$, GI Pi $6115 ; 15$, GI Pi 5747; 16, GI Pi 5758; 17 , GI Pi 5746; 18 , GI Pi $5762 ; 19$, GI Pi 5745; 20, GI Pi 5756; 21, GI Pi 7285; 22, GI Pi 7282; 23, GI Pi 5755; 24, GI Pi 5760; 25 , GI Pi 7284; 26, GI Pi 5744; 27, GI Pi 5754; 28, GI Pi 5759; 29, GI Pi 5743; 30, GI Pi 5761; 31, GI Pi 7286; 32, GI Pi 7287; 33, GI Pi 7288; 34, GI Pi 7289.

Estonia, Saaremaa, Sakla bore core, depth $62.55-62.70 \mathrm{~m}$, Tagavere Beds of Jaagarahu Stage, Wenlock, lower Silurian. 


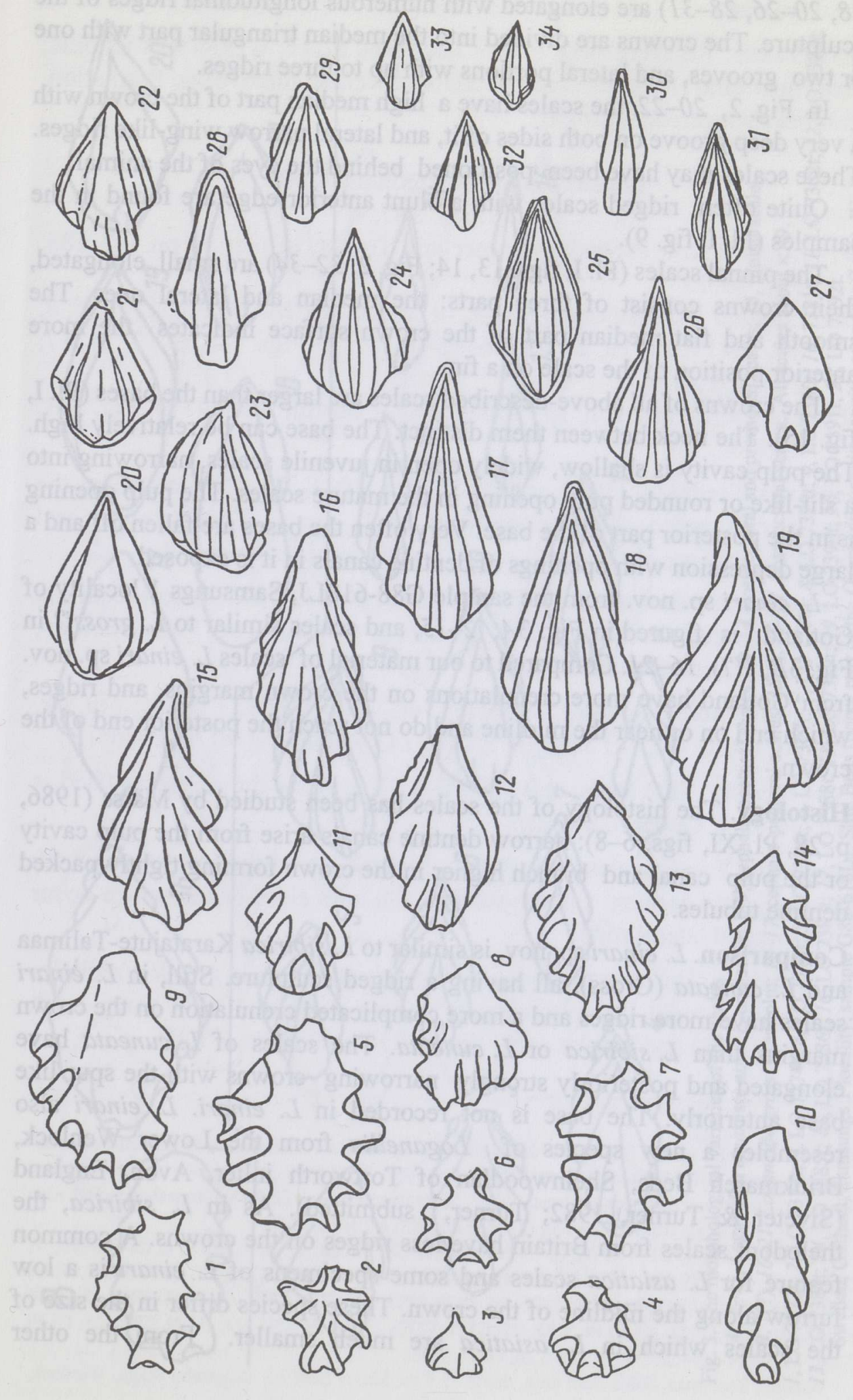


Postpectoral and precaudal (trunk) scales (P1. I, figs. 9-12; Fig. 2, 17, $18,20-26,28-31)$ are elongated with numerous longitudinal ridges of the sculpture. The crowns are divided into the median triangular part with one or two grooves, and lateral portions with up to three ridges.

In Fig. 2, 20-22, the scales have a high median part of the crown with a very deep groove on both sides of it, and lateral narrow wing-like ridges. These scales may have been positioned behind the eyes of the animal.

Quite often ridged scales with a blunt anterior edge are found in the samples (Pl. I, fig. 9).

The pinnal scales (Pl. I, figs. 13, 14; Fig. 2, 32-34) are small, elongated, their crowns consist of three parts: the median and lateral ones. The smooth and flat median part of the crown surface indicates the more anterior position of the scale on a fin.

The crowns of all above-described scales are larger than the bases (Pl. I, fig. 15). The neck between them distinct. The base can be relatively high. The pulp cavity is shallow, widely open in juvenile scales, narrowing into a slit-like or rounded pulp opening in the mature scales. The pulp opening is in the posterior part of the base. Very often the bases are fallen off and a large depression with openings of dentine canals in it is exposed.

L. einari sp. nov. from the sample G88-618LJ, Samsungs 1 locality of Gotland, is figured in Fig. 3A, 2-15, and scales similar to L. grossi? in Fig. 3B, 1(?), 16-21. Compared to our material of scales $L$. einari sp. nov. from Gotland have more crenulations on the crown margins, and ridges, which end on or near the midline and do not reach the posterior end of the crown.

Histology. The histology of the scales has been studied by Märss (1986, p. 28 , Pl. XI, figs. 6-8): narrow dentine canals arise from the pulp cavity or the pulp canal and branch higher in the crown forming tightly packed dentine tubules.

Comparison. L. einari sp. nov. is similar to L. sibirica Karatajute-Talimaa and $L$. cuneata (Gross), all having a ridged sculpture. Still, in L. einari scales have more ridges and a more complicated crenulation on the crown margins than L. sibirica or L. cuneata. The scales of L. cuneata have elongated and posteriorly strongly narrowing crowns with the spur-like base anteriorly. The base is not recorded in L. einari. L. einari also resembles a new species of Loganellia from the Lower Wenlock, Brinkmarch Beds, Sheinwoodian of Tortworth inlier, Avon, England (Siveter \& Turner, 1982; Turner, submitted). As in L. sibirica, the thelodont scales from Britain have less ridges on the crowns. A common feature for $L$. asiatica scales and some specimens of $L$. einari is a low furrow along the midline of the crown. These species differ in the size of the scales which in L. asiatica are much smaller. From the other 


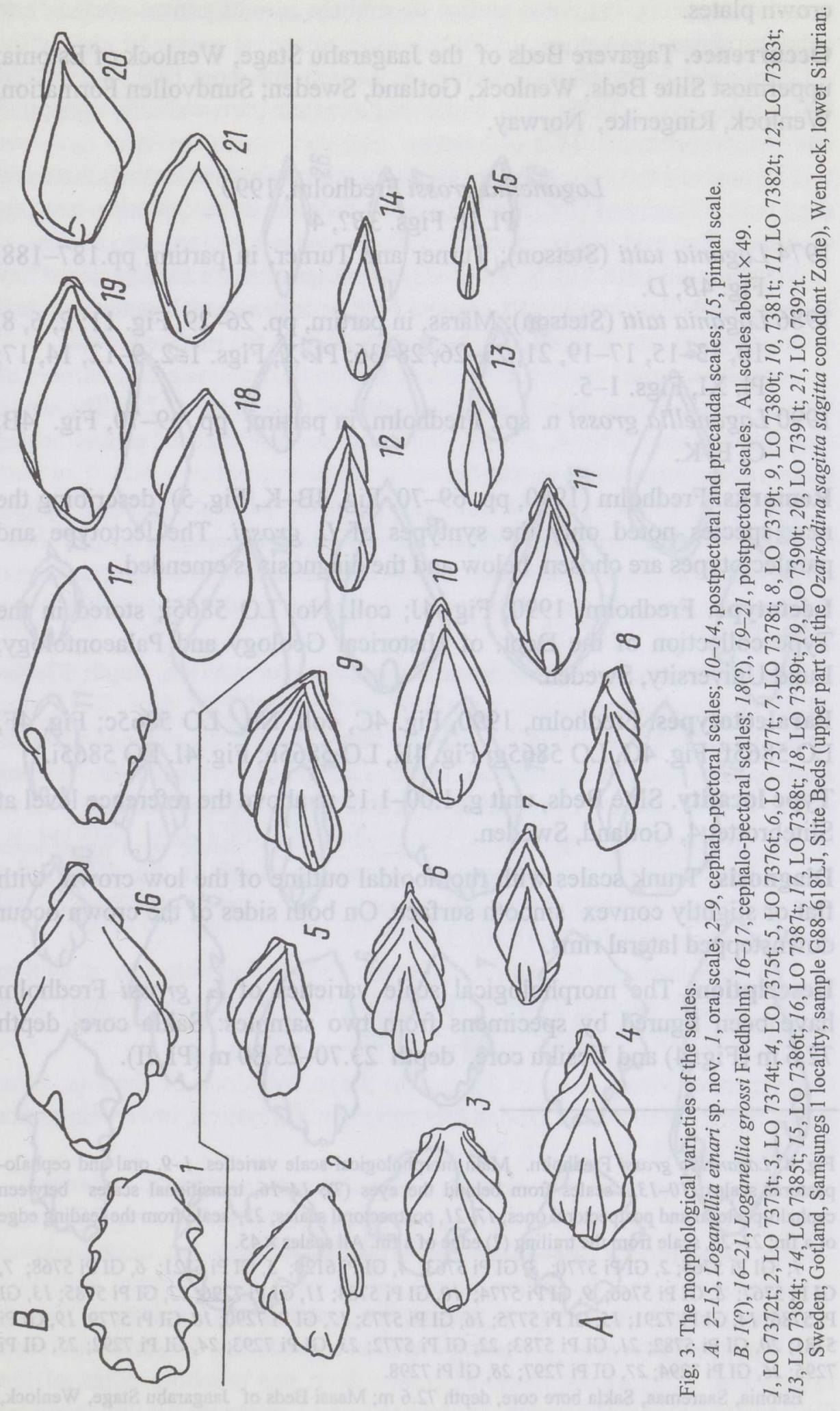


Loganellia species L. einari differs in lacking rhomboidal flat smooth crown plates.

Occurrence. Tagavere Beds of the Jaagarahu Stage, Wenlock of Estonia; uppermost Slite Beds, Wenlock, Gotland, Sweden; Sundvollen Formation, Wenlock, Ringerike, Norway.

\section{Loganellia grossi Fredholm, 1990}

Pl. II; Figs. $3 B$ ?, 4

1974 Logania taiti (Stetson); Turner and Turner, in partim, pp.187-188, Fig. $4 B, D$.

1986 Logania taiti (Stetson); Märss, in partim, pp. 26-29, Fig. 11: 2, 6, 8, 10, 13-15, 17-19, 21, 23-26, 28-36; Pl. X, Figs. 1-2, 9-12, 14, 17; Pl. XI, Figs. 1-5.

1990 Loganellia grossi n. sp.; Fredholm, in partim, pp. 69-70, Fig. 4B, C, E-K.

Remarks. Fredholm (1990, pp. 69-70, Fig. 4B-K, Fig. 5) describing the new species noted only the syntypes of $L$. grossi. The lectotype and paralectotypes are chosen below and the diagnosis is emended.

Lectotype. Fredholm, 1990, Fig. 4J; coll. No. LO 5865j; stored in the Type collection of the Dept. of Historical Geology and Palaeontology, Lund University, Sweden.

Paralectotypes. Fredholm, 1990, Fig. 4C, coll. No. LO 5865c; Fig. 4F, LO 5865f; Fig. 4G, LO 5865g; Fig. 4H, LO 5865h; Fig. 4I, LO 5865 i.

Type locality. Slite Beds, unit g, 1.00-1.15 $\mathrm{m}$ above the reference level at Slitebrottet 4, Gotland, Sweden.

Diagnosis. Trunk scales with rhomboidal outline of the low crown, with flat or slightly convex smooth surface. On both sides of the crown occur downstepped lateral rims.

Description. The morphological scale varieties of $L$. grossi Fredholm have been figured by specimens from two samples: Sakla core, depth $72.6 \mathrm{~m}$ (Fig. 4) and Vesiku core, depth $23.70-23.80 \mathrm{~m}$ (Pl. II).

Fig. 4. Loganellia grossi Fredholm. Main morphological scale varieties. 1-9, oral and cephalopectoral scales; 10-13, scales from behind the eyes (?); 14-16, transitional scales between cephalo-pectoral and postpectoral ones; $17-21$, postpectoral scales; 22 , scale from the leading edge of a fin; 23-28, scale from the trailing (?) edge of a fin. All scales $\times 45$.

1, GI Pi 5765; 2, GI Pi 5770; 3, GI Pi 5763; 4, GI Pi 6120; 5, GI Pi 6121; 6, GI Pi 5768; 7 , GI Pi 5767; 8, GI Pi 5766; 9, GI Pi 5774; 10, GI Pi 5784; 11, GI Pi 7296; 12, GI Pi 5785; 13, GI Pi 5786; 14, GI Pi 7291; 15 , GI Pi 5775; 16, GI Pi 5773; 17 , GI Pi 7290; 18 , GI Pi 5779; 19 , GI Pi 5781; 20, GI Pi 5782; 21, GI Pi 5783; 22, GI Pi 5772; 23, GI Pi 7293; 24, GI Pi 7292; 25, GI Pi 7295; 26, GI Pi 7294; 27, GI Pi 7297; 28, GI Pi 7298.

Estonia, Saaremaa, Sakla bore core, depth $72.6 \mathrm{~m}$; Maasi Beds of Jaagarahu Stage, Wenlock, lower Silurian. 


$$
\theta_{0} 0_{0}
$$

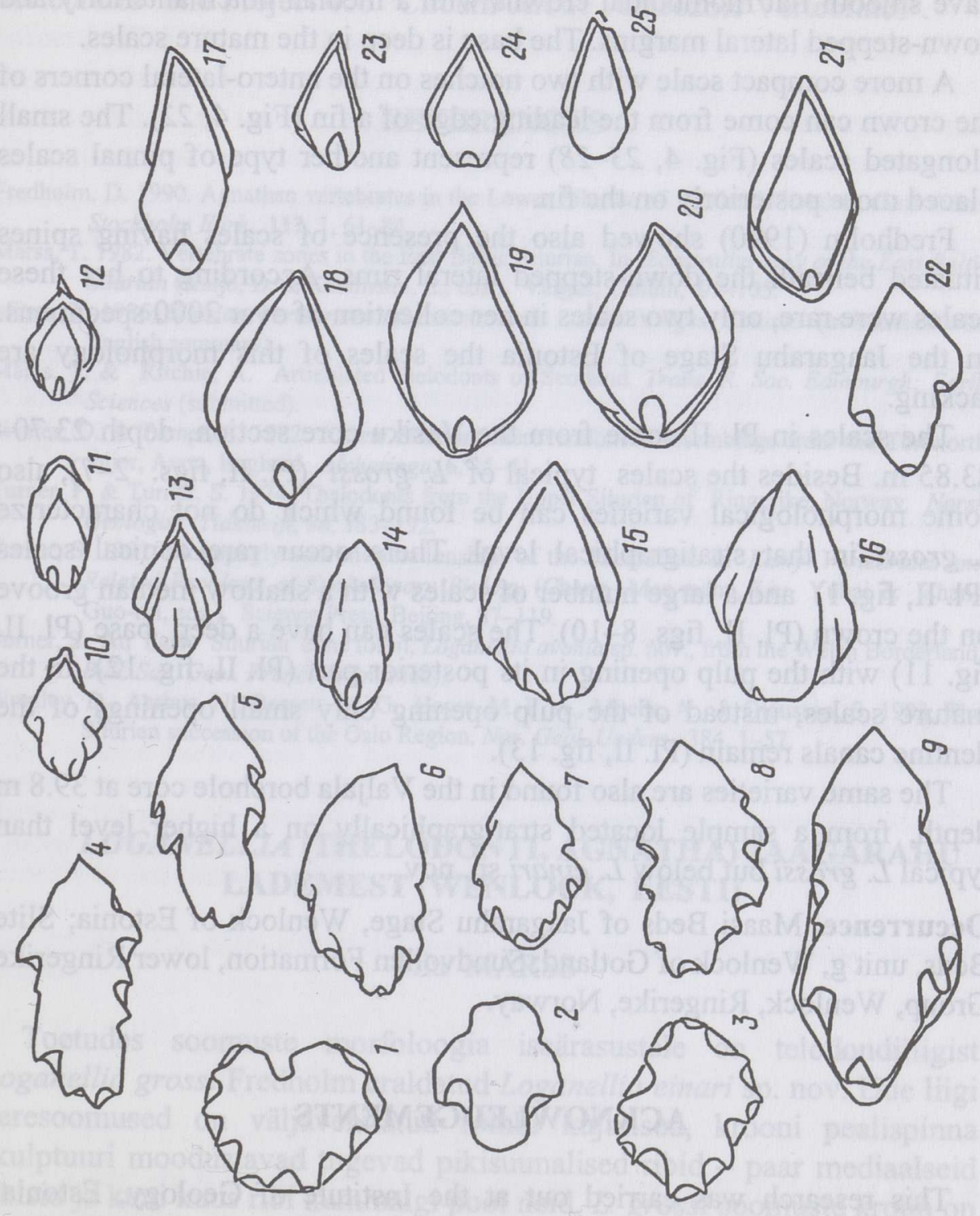


Configuration of the oral and cephalo-pectoral scales (Fig. 4, 1-9) is rounded to elongated, with a flat or slightly convex crown surface and crenulated margins.

Very specific small scales (Fig. 4, 10-13) are most probably placed behind the eyes. They have a distinct median part and down-stepped lateral margins comprising 1-3 steps.

The scales 14-16 in the same figure have transitional features between cephalo-pectoral and postpectoral scales: notches in the anterior margins on the median part of the crown, and down-stepped postero-lateral rims.

Postpectoral scales (Fig. 4, 17-21) are diagnostic for the species. They have smooth flat rhomboidal crowns with a median notch anteriorly and down-stepped lateral margins. The base is deep in the mature scales.

A more compact scale with two notches on the antero-lateral corners of the crown can come from the leading edge of a fin (Fig. 4, 22). The small elongated scales (Fig. 4, 23-28) represent another type of pinnal scales placed more posteriorly on the fin.

Fredholm (1990) showed also the presence of scales having spines situated beneath the down-stepped lateral rims. According to her these scales were rare, only two scales in her collection of over 2000 specimens. In the Jaagarahu Stage of Estonia the scales of this morphology are lacking.

The scales in Pl. II come from the Vesiku core section, depth 23.70 $23.85 \mathrm{~m}$. Besides the scales typical of L. grossi (Pl. II, figs. 2-7), also some morphological varieties can be found which do not characterize L. grossi in that stratigraphical level. There occur rare conical scales (Pl. II, fig. 1) and a large number of scales with a shallow median groove on the crown ( $\mathrm{Pl}$. II, figs. 8-10). The scales can have a deep base (Pl. II, fig. 11) with the pulp opening in its posterior part (Pl. II, fig. 12). In the mature scales, instead of the pulp opening only small openings of the dentine canals remain (Pl. II, fig. 13).

The same varieties are also found in the Valjala borehole core at $39.8 \mathrm{~m}$ depth, from a sample located stratigraphically on a higher level than typical L. grossi but below L. einari sp. nov.

Occurrence. Maasi Beds of Jaagarahu Stage, Wenlock of Estonia; Slite Beds, unit g, Wenlock of Gotland; Sundvollen Formation, lower Ringerike Group, Wenlock, Ringerike, Norway.

\section{ACKNOWLEDGEMENTS}

This research was carried out at the Institute of Geology, Estonia. Funding was provided by grant No. 1666 from the Estonian Science Foundation. Part of the material comes from the borehole cores of the Geological Survey of Estonia. My trip to Lund University was financed by 
the IUGS/UNESCO (for the IGCP Project 328) and Svenska Institutet. D. Fredholm and L. Jeppsson, Lund, kindly allowed me to study their collections of scales, helpfully discussed the biostratigraphy of the Silurian of Gotland, and gave permission to publish the set of scales from the Samsungs 1 locality. D. Kaljo and M. Rubel carefully read the draft of the text and offered many valuable suggestions. K. Ronk prepared the illustrations, U. Moldov and G. Baranov photographed the scales and made the prints, respectively. My sincere thanks are due to all these people.

This is a contribution to the IGCP Project 328 "Palaeozoic Microvertebrates" and Project 406 "Circum-Arctic Palaeozoic Vertebrates".

\section{REFERENCES}

Fredholm, D. 1990. Agnathan vertebrates in the Lower Silurian of Gotland, Sweden. Geol. För. $i$ Stockholm Förh., 112, 1, 61-84.

Märss, T. 1982. Vertebrate zones in the East Baltic Silurian. In Ecostratigraphy of the East Baltic Silurian (Kaljo, D. \& Klaamann, E., eds.). Valgus, Tallinn, 97-105.

Märss, T. 1986. Silurian Vertebrates of Estonia and Latvia. Valgus, Tallinn (in Russian with English summary).

Märss, T. \& Ritchie, A. Articulated thelodonts of Scotland. Trans. R. Soc. Edinburgh: Earth Sciences (submitted).

Siveter, D. \& Turner, S. 1982. A new Silurian microvertebrate assemblage from the Tortworth inlier, Avon, England. Alcheringa, 6, 35-41.

Turner, P. \& Turner, S. 1974. Thelodonts from the Upper Silurian of Ringerike, Norway. Norsk Geologisk Tidsskrift, 54, 183-192.

Turner, S. 1991. Monophyly and interrelationships of the Thelodonti. In Early Vertebrates and Related Problems of Evolutionary Biology (Chang Mee-mann, Liu Yuhai \& Zhang Guo-rui, eds.). Science Press, Beijing, 87-119.

Turner, S. An Early Silurian zone fossil, Loganellia avonia sp. nov., from the Welsh Borderland. Bull. Soc. Geol. France (submitted).

Worsley, D., Aarhus, N., Bassett, M. G., Howe, M. P. A., Moerk, A. \& Olaussen, S. 1983. The Silurian succession of the Oslo Region. Nor. Geol. Unders., 384, 1-57.

\section{LOGANELLIA (THELODONTI, AGNATHA) JAAGARAHU LADEMEST (WENLOCK, EESTI)}

\section{Tiiu MÄRSS}

Toetudes soomuste morfoloogia iseärasustele on telodondiliigist Loganellia grossi Fredholm eraldatud Loganellia einari sp. nov. Uue liigi keresoomused on väljavenitatud rombi kujulised, krooni pealispinna skulptuuri moodustavad tugevad pikisuunalised ribid - paar mediaalseid ribisid ja kuni kuus ribi kummalgi pool neid. L. grossi soomuste kroon on lame, sile, väikese lohukesega eesservas; kummalgi pool krooni, sellest veidi madalamal, asub rant. Kahe liigi olemasolule Jaagarahu eal annab kinnitust nende fossiilide erinev stratigraafiline asend läbilõigetes - 
L. einari sp. nov. leviku algus on alati kõrgemal kui L. grossi oma. Viimane tõsiasi võimaldab püstitada $L$. einari tsooni Wenlockis Jaagarahu lademe Tagavere kihtides.

L. grossi Fredholm on uuesti kirjeldatud.

\section{LOGANELLIA (THELODONTI, AGNATHA) ИЗ ВЕНЛОКА ЯАГАРАХУСКОГО ГОРИЗОНТА ЭСТОНИИ}

\section{Тийу МЯРСС}

На основе морфологии чешуй из телодонтового вида Loganellia grossi выделен Loganellia einari sp. nov. Чешуи туловища нового вида удлиненные, ромбовидные, поверхность кроны скульптирована из отчетливых продольных ребрышек - из одной пары медиальных и до шести по обоим сторонам последних. Крона чешуй L. grossi плоская, гладкая, с небольшим медиальным углублением спереди и с уступчатым понижением по краям. Наличие двух видов подтверждается и их различным стратиграфическим положением в разрезах - начало распространения $L$. einari sp. nov. всегда выше, чем L. grossi. Последний факт позволяет установить зону L. einari в венлоке, в тагавереских слоях яагарахуского горизонта. Зона имеет региональное значение.

Дано повторное описание L. grossi Fredholm. 